We are faced with a crisis but we have responded with apathy, and unconsciously decided not to react to the crisis at all. At the same time, everyone we meet is has some concern and appreciation for at least part of the environment. How does this split in our thinking persist? Our society has grown so used to taking the world for granted that we can neither be shocked nor shamed into doing anything about the ecological crisis because we are inundated with other more shocking news every day and we have made the decision that we will continue to exist without paying attention to the evidence before our eyes. This decision, expressed by psychologist Harold Searles, gave Nicholsen the idea for the book. Our decision, Nicholsen wants us to know, is wrong and a denial of the evidence we can see as well as denying North American Native wisdom, Christianity, Islam, and Buddhism among other teachings of the ages. Artists, philosophers, and teachers of nature all give evidence of what we are missing, and what we are destroying, but we do not

\section{Survival by Hunting: Prehistoric Human Predators and Animal Prey}

By G. Frison. 2004. University of California Press, Berkeley. xix +266 pages. Can $\$ 47.25$ Cloth.

The archaeological excavations in which I have been involved in interior western Canada often yield large amounts of animal bone, eloquent testimony to the importance of hunting for people in the past. Like most modern urban people, however, I have never hunted or butchered animals and so my ability to understand what I see in the archaeological record lacks this source of enrichment. In his fine book, Survival by Hunting, George Frison argues that direct hunting experience is a fundamental source of knowledge for archaeologists and laments the fact that most know nothing of this activity. He expresses his "dissatisfaction with ethnographic and archaeological interpretations of human hunters and hunting that fail to acknowledge the years of experience and the accumulation of knowledge of animal behaviour required to become a successful hunter." In Chapter 9 ("Concluding Thoughts"), he reiterates his frustration "that human hunting has wrongly been viewed as a kind of instinctive behaviour not worthy of serious anthropological study." On the contrary, he states that " killing an animal' hardly describes the body of learned behaviour acquired over a long period of time that leads to that final act." $\mathrm{He}$ argues persuasively for an experiential approach to archaeology, using his own life and career as exemplars. As such, this book contains a great deal of information about animal behaviour and biology, though viewed from the perspective of a hunter.

Although he does not express it in quite these terms, my reading of Frison's argument suggests that he is impatient with the attitude of students who regard hunting and killing an animal as easy, whereas they regard the butchering and use of the remains as the difficult part requiring interpretation. Perhaps this is because the respond because we have already made up our minds not to take the wisdom into account.

The book recognizes that our relationship with our world is destructive and has always been so, from the moment when we began to kill wildlife and uproot plants to nourish ourselves. However, killing and uprooting are only the beginning and not the end of our relationship with our world as we know, but could well become the fulfilment and fate of the world if we cannot see beyond incidentals. This book is an opportunity to see beyond where we are, which direction we seem to be going and an invitation to visit the wisdom of the ages. The sages teach us that the progress of nature does not despair of the possibilities of the future and neither should we. Nicholsen shows us a bleak path of destruction, but with the thread of hope that nature itself interpreted by writers past and present can lead us back to a positive relationship with the world in which we live.

JIM O’NEILL

28718 Five Mile Road, Livonia, Michigan 48154 USA

process of hunting, as opposed to the kill and carcass use, leaves scant archaeological remains. Certainly, there are sites, such as Head-Smashed-In Buffalo Jump in southwest Alberta, where drive lanes and terrain configuration allow some reconstruction of the hunting strategy. But in most cases, especially where sites are deeply buried, this level of information cannot be recovered. The hunting process, as Frison describes it, involves an intimate knowledge of animal behaviour with a sophisticated understanding of terrain, and demands adaptability, persistence, and considerable strength and physical skill. Much of this, therefore, resides in the mind of the hunter and not in the material culture or discarded faunal remnants found at an archaeological site.

The first two chapters ("Where the Buffalo Once Roamed" and "The Education of a Hunter") draw largely on Frison's own life experience. He describes how he grew up in northern Wyoming in the 1920s and 1930s, learning to ride and hunt with his grandfather, partly to undertake predator control, and partly to supplement the food supply on the ranch. He spent much of his early adult life as an outfitter and guide. He recounts how his interest in archaeology grew from his encounters with sites and artifacts while he was out on the land. His fascination with this material and the people of the past who made it increased, until finally, in the 1960s, he was persuaded to enter the academic world, gaining formal training in the field that absorbed him. In the decades since then, he has excavated and published accounts of many of the most widely-known archaeological sites in the interior northwestern United States. These include the Casper site, Agate basin site, Horner site, and Mill Iron site. Perhaps because he was an outdoorsman first and an archaeologist second, his work has always included, perhaps to a greater ex- 
tent than many other contemporary archaeologists, an appreciation for the subtleties of the terrain around the sites.

The heart of the book concentrates on the hunting of the large mammals that were major food sources for people through the past eleven millennia. The regional focus is the interior of North America, mainly the northern Great Plains and adjacent Rockies of the United States, the areas where Frison has spent most of his life and career. Frison begins his survey by considering Paleoindian, notably Clovis, hunters and the approaches they might have taken to hunting the now extinct megafauna, especially mammoths, around 11500 to 10000 years ago. This chapter is more speculative than the rest and, because there are no mammoths around to hunt today, it is obviously less based in personal experience. Elephants, perhaps, are the nearest one can now get to mammoths, though it is unclear how closely their behaviour and reactions to hunting are analogous. Frison describes some butchering experiments undertaken during elephant culls in Zimbabwe. From his account, cutting up an elephant with a stone knife is a lengthy, messy, and tiring process!

The next three chapters each focus on one of the "big three" prey mammals of the northern plains and Rockies: Bison, Pronghorn, and Mountain or Big Horn Sheep. As merits its importance in the archaeological record, the bulk of this discussion (almost 60 pages) focusses on Bison. This chapter begins with a consideration of the palaeontological evidence for different Bison species - a subject about which there is still much debate - followed by a survey of selected archaeological Bison kill sites. Frison reviews the several strategies that were used to hunt and kill Bison, resulting in kill sites of different types including arroyo traps, Bison jumps, and corrals. He then presents some interesting observations of Bison behaviour based on Bison ranching, knowledge that is needed in order to judge how the animals might react to various situations. One point that comes through strongly from these accounts is that cattle are not a good analogue for Bison because their behaviour and biology are quite different. Frison structures sections on Pronghorn and Big Horn Sheep in the same way, with an introduction to the animals' biology, ecology, and behaviour, emphasizing traits, such as herding, that would affect hunting strategies. He summarizes ethnographic accounts of hunting and then describes the archaeological signatures of procurement. These are often different and characteristic for each animal: corrals for Pronghorn and small traps or pens made of logs for Big Horn Sheep in the high country.

Chapter 7 deals with the hunting of various other animals in the same region. These include large animals - specifically deer, both White-tailed and Mule deer, Elk, and Black and Grizzly bear - and small mammals, especially rodents, and birds. Although sometimes present, these tend not to feature as promi- nently in the faunal assemblages from archaeological sites in the regions under consideration. Indeed, Frison questions whether "small mammal procurement should be considered in the category of 'hunting", Nevertheless, birds and small mammals may have been important diet items in some circumstances, although perhaps not as "archaeologically visible" as large mammals. The discussion of birds is quite brief and deals with only two (Sage Grouse and Blue Grouse); I found it interesting that there was no discussion of waterfowl hunting. Frison comments (page 178) that he has no experience with hunting Caribou, another large mammal that was an important food source for people further north. Frison briefly describes an unusual arrangement of canid faunal remains. Although this seems one implication, he does not discuss potential ceremonial aspects to this arrangement, while he does mention possible ceremonial aspects to arrangements of Elk antlers and Big Horn Sheep horns. However, throughout this book, Frison's focus is on hunting animals for food; other possible reasons for animal procurement are only touched on tangentially.

Throughout these chapters, Frison has mentioned the various weapons that were used in hunting. Chapter 8 brings this together and concentrates more explicitly on "Weaponry and Tools Used by the Hunter". The main weapons include the spear, the bow and arrow, and the atlatl. Stone tools include those used to butcher and process an animal, such as knives, hammers, and scrapers. With respect to these weapons and tools, our perceptions may be strongly coloured by what is recovered at archaeological sites, that is, mainly artifacts made of stone, although Frison does include some discussion of weapons and tools made from other materials, such as bone, antler and ivory. There is a further bias in the archaeological record because only part of the weapon system, the projectile point, is usually recovered. The other essential parts of the technology, such as wooden spear shafts, sinew lashings, bow strings, etc., which are made from more perishable materials, are rarely preserved in this region, except in unusual settings such as dry caves.

This is a truly fascinating book. It is a "must read" for professionals involved in archaeology, and plains archaeology especially. But anyone with an interest in the lifeways of people in North America prior to European settlement will find much to ponder on here. For naturalists, the main interest of the book lies in the practical observations on behaviour of some major large mammals of the continental interior. A career statement from one of the towering figures in late $20^{\text {th }}$ century North American archaeology, this volume represents the distillation of a lifetime's experience garnered by fieldwork and reflection.

Alwynne B. Beaudoin

Royal Alberta Museum, 12845102 Avenue, Edmonton, Alberta T5N 0M6 Canada 